DOI : 10.33451/florafauna.v26i1pp22-28

FLORA AND FAUNA

ISSN 2456 - 9364 (Online)

2020 Vol. 26 No. 1 PP 22-28

ISSN 0971 - 6920 (Print)

\title{
Effect of different algal powder on growth and productivity of Moongbean (Phaseolus radiata)
}

B.B. Mahadik and *P.S. Kabnoorkar

\author{
Department of Botany, \\ Arts, Science and Commerce College, \\ INDAPUR-413106 Dist. PUNE (MS) INDIA. \\ ${ }^{*}$ Corresponding Author \\ E-mail : pkabnoorkar@gmail.com
}

Received : 30.03.2020; Revised : 30.04.2020; Accepted : 02.05.2020

\begin{abstract}
Various species of algae grow luxuriantly in Ujani reservoir. Those species found in large amount are used for experimental purpose. The effect of selected five algal species (Synechococcus aeruginosus, Spirulina plantensis, Cladophora crispata, Spirogyra jugalis and Chara fragilis) was evaluated as biofertilizer on growth and productivity of Moongbean. From the study it was observed that application of algae on Moongbean gives higher yield compared to control. Statistical analysis showed that there are significant differences in plant height,number of leaves and yield as compared to control.

Figures : 02

References : 17

Table : 01

KEY WORDS : Algal powder, Growth and Productivity, Phaseolus radiata L., Yield.
\end{abstract}

\section{Introduction}

Ujani reservoir is rich in algal biodiversity. Various species of algae are found in Ujani reservoir mainly Chara fragilis, Spirogyra jugalis, Synechococcus aeruginosus, Spirulina platensis, Cladophora crispata, Chara excelsa, Microcystis aeruginosa, etc.

Among these Cladophora crispata, Spirogyra jugalis, Chara fragilis, Synechococcus aeruginosus, Spirulina platensis are found in large quantities. For these experiments Moongbean (variety Kopargaon) was selected. These crops are the main crops cultivated in Indapur Taluka. For growth and development of these crops suitable environment is there in Indapur Taluka.

Moongbean is an important source of protein and has a great economic value in national market. These crops have a short season for harvesting.In rainfed areas Moongbean (Kopargaon) is cultivated on large scale and in well irrigated land, productivity increases.

For this experiment algae was considered as a biofertilizer because it helps in $\mathrm{N}_{2}$ fixation. Algal extracts which are known to enhance seed germination, improve plant growth, and induce resistance to frost, fungal and insect attack and increase nutrient uptake from soil $7,15-17$. The recent researches proved that seaweed fertilizers are preferred not only due to their nitrogen, phosphorus and potash content but also because of the presence of trace elements and metabolite similar to plant growth regulators such as auxin, cytokinin and gibberellins.

Addition of different successive extracts of Asparogopsis taxiformis thallus powder to the soil, as a biofertilizer, gave significant increase in the growth of Vicia $f a b a^{2}$. The application of an extract from algae to soil or foliage increased ash, protein and carbohydrate content of potatoes ${ }^{5}$. NPK in plants treated with Sargassum sp., reached four folds the negative control ${ }^{10}$.

Studies of the algal influence on growth, yield and protein content of rice plants and showed that pre-soaking rice seeds with BGA cultures or extracts enhance germination, promote the growth of roots and shoots and increase the weight and protein content of the grain ${ }^{3}$. Beneficial effects of cyanobacterial inoculation were reported, not only for rice, but for other crops such as wheat, soybean, oat, tomato, radish, cotton, sugarcane, maize, chili, bean, muskmelon and lettuce ${ }^{1-4,6,8,11-14,16}$. Several reasons have been proposed for beneficial effects of cyanobacteria on the growth of different plants.

It was observed that the continuous application of inorganic fertilizers, soil become nonfertile. Inorganic fertilizers are costly so now a days people began to use alternative sources like organic fertilizers \& biofertilizers. 
TABLE-1 : Effect of different Algal Powder on Growth and Productivity of Moongbean

\begin{tabular}{|c|c|c|c|c|c|c|}
\hline Pot & $\begin{array}{l}\text { No. of leaves } \\
\text { after } 21 \text { days } \\
\quad(\mathrm{cm})\end{array}$ & $\begin{array}{l}\text { Height of } \\
\text { Plant at } \\
\text { harvesting } \\
\text { time }(\mathrm{cm})\end{array}$ & $\begin{array}{l}\text { No. of } \\
\text { pods } \\
\text { Per } \\
\text { plant }\end{array}$ & $\begin{array}{l}\text { Total } \\
\text { No. } \\
\text { of } \\
\text { grains }\end{array}$ & $\begin{array}{l}\text { Average } \\
\text { length } \\
\text { of Pod } \\
\text { (cm) }\end{array}$ & $\begin{array}{c}\text { Total } \\
\text { weight } \\
\text { of seeds } \\
\text { on Plant } \\
\text { (g) }\end{array}$ \\
\hline Soil & $11 \pm 0.66$ & $24 \pm 0.57$ & $13 \pm 0.57$ & $105 \pm 1$ & $8.9 \pm 0.11$ & $6.690 \pm 0.05$ \\
\hline Soil+ compost & $12 \pm 0.57$ & $25 \pm 0.57$ & $16 \pm 0.57$ & $133 \pm 1.15$ & $9.5 \pm 0.05$ & $7.850 \pm 0.02$ \\
\hline$S+A 1$ & $12 \pm 0.57$ & $28 \pm 1$ & $16 \pm 1$ & $139 \pm 1$ & $7.6 \pm 0.17$ & $7.210 \pm 0.01$ \\
\hline $\mathrm{S}+\mathrm{A} 2$ & $14 \pm 1.2$ & $30 \pm 1$ & $17 \pm 0.57$ & $140 \pm 0.57$ & $9.9 \pm 0.1$ & $8.960 \pm 0.01$ \\
\hline$S+A 3$ & $13 \pm 0.57$ & $29 \pm 0.57$ & $15 \pm 0.57$ & $115 \pm 0.57$ & $9.2 \pm 0.15$ & $7.640 \pm 0.01$ \\
\hline $\mathrm{S}+\mathrm{A} 4$ & $14 \pm 0.57$ & $30 \pm 1$ & $14 \pm 0.57$ & $104 \pm 1.15$ & $8.7 \pm 0.15$ & $6.890 \pm 0.01$ \\
\hline $\mathrm{S}+\mathrm{A} 5$ & $12 \pm 1$ & $28 \pm 0.57$ & $13 \pm 1$ & $102 \pm 0.57$ & $8.7 \pm 0.1$ & $6.840 \pm 0.01$ \\
\hline$S+C+A 1$ & $12 \pm 1$ & $28 \pm 1$ & $18 \pm 1$ & $123 \pm 1$ & $7.8 \pm 0.05$ & $8.000 \pm 0.01$ \\
\hline$S+C+A 2$ & $16 \pm 0.57$ & $29 \pm 0.57$ & $19 \pm 1.15$ & $151 \pm 1$ & $10.3 \pm 0.11$ & $9.780 \pm 0.03$ \\
\hline$S+C+A 3$ & $15 \pm 1$ & $29 \pm 0.57$ & $17 \pm 0.57$ & $157 \pm 1$ & $10.3 \pm 0.15$ & $10.090 \pm 0.03$ \\
\hline $\mathrm{S}+\mathrm{C}+\mathrm{A} 4$ & $17 \pm 1$ & $30 \pm 1$ & $20 \pm 1.15$ & $178 \pm 1.15$ & $10.5 \pm 0.20$ & $12.480 \pm 0.01$ \\
\hline$S+C+A 5$ & $16 \pm 0.57$ & $29 \pm 1.15$ & $18 \pm 1$ & $154 \pm 0.57$ & $9.1 \pm 0.15$ & $8.890 \pm 0.36$ \\
\hline$S+N P K+A 1$ & $15 \pm 1$ & $26 \pm 0.57$ & $18 \pm 1$ & $131 \pm 1$ & $7.5 \pm 0.20$ & $8.620 \pm 0.01$ \\
\hline$S+N P K+A 2$ & $16 \pm 1$ & $28 \pm 1$ & $21 \pm 1.15$ & $191 \pm 0.57$ & $8.8 \pm 0.32$ & $10.970 \pm 0.01$ \\
\hline $\mathrm{S}+\mathrm{NPK}+\mathrm{A} 3$ & $18 \pm 1$ & $30 \pm 1$ & $19 \pm 1$ & $158 \pm 1$ & $10.2 \pm 0.03$ & $10.120 \pm 0.01$ \\
\hline $\mathrm{S}+\mathrm{NPK}+\mathrm{A} 4$ & $19 \pm 0.57$ & $32 \pm 0.57$ & $22 \pm 0.57$ & $193 \pm 1$ & $10.7 \pm 0.17$ & $12.270 \pm 0.03$ \\
\hline $\mathrm{S}+\mathrm{NPK}+\mathrm{A} 5$ & $17 \pm 1.05 s$ & $31 \pm 0.57$ & $19 \pm 1$ & $152 \pm 0.57$ & $9.8 \pm 0.15$ & $10.030 \pm 0.01$ \\
\hline \multicolumn{7}{|c|}{${ }^{*} \mathrm{~S}=$ Soil ${ }^{*} \mathrm{C}=$ Compost $\quad * N P K=19: 19: 19$} \\
\hline
\end{tabular}


Blue- green algae as well as other algal members are the good sources of biofertilizer. But it has less attention to use of algae as a biofertilizer. That's why we decided to study the effect of selected algae (two algal members of Blue green algae (Synechococcus aeruginosus and Spirulina plantensis) and other algal members namely Cladophora crispata, Spirogyra jugalis and Chara fragilis) on crop productivity.

\section{Materials and Methods}

\section{Algae collection and preparation:}

Fresh algae of Cladophora crispata, Spirogyra jugalis, Chara fragilis, Synechococcus aeruginosus, Spirulina platensis were collected from different locations: Taratgaon, Kandalgaon, Malwadi, Kalthan, Palasdev, Dalaj, and Takrarwadi of Ujani reservoir, Maharashtra, India. Then the algae were washed thoroughly with tap water to remove extraneous materials and brought to the laboratory in plastic bags containing water to prevent evaporation. Samples were then shade dried until constant weight obtained. . After drying, fine powder was prepared in grinder. The powdered samples subsequently stored in refrigerator until used.

\section{Plant material}

Seeds of Moongbean (Phaseolus radiate L.), were surface sterilized with ethanol $70 \%$ and washed by sterile distilled water, then dried in shadow open air. The seeds were planted in $30 \mathrm{~cm}$ diameter earthen pots containing mixture of 1:1 autoclaved peat and sand soil. Every pot contained 01 seed. They watered every week.

\section{Growth measurements}

Numbers of leaves after 21 days of plantation, plant height at the time of harvesting and total yields of selected crops were recorded.

\section{The treatments}

For the above said purpose the experiment was carried out in different five sets.

1. First set was considered as control was treated with only sterilized soil (10kg).

2. Second set was arranged with sterilized soil and compost (10kg sterilized soil $+100 \mathrm{~g}$ compost).

3. Third set $10 \mathrm{~kg}$ sterilized soil $+100 \mathrm{~g}$ algal powder of five selected algae were mixed well and used for the same experiment.

4. Fourth experimental set $10 \mathrm{~kg}$ sterilized soil and $100 \mathrm{~g}$ compost (organic fertilizer) along with different selected algal powder $100 \mathrm{~g}$ mixed well and used for the fourth experimental set.

5. Fifth experimental set $10 \mathrm{~kg}$ sterilized soil $+100 \mathrm{~g}$ NPK(19:19:19) Inorganic fertilizer + 100g algal powder of five selected algae.
According to our aim to observe the effect of different algal powder on growth and productivity the experiment was carried out in triplicate and in three different seasons.

To check the growth and productivity of Moongbean some parameters were considered such as number of leaves per plant after 21 days, height of the plant after maturity, number of pods per plant, total number of grains (seed) and total weight of seeds per plant (yield)

\section{Results and Discussion}

Compared to all experimental sets less number of grains i.e. 105 obtained in controlled condition. (Plants grow with soil only).Moongbean cultivated under controlled condition gave minimum yield $6.69 \mathrm{~g}$ i.e. total weight of seeds per plant.Eleven leaves recorded after 21 days of growth and $24 \mathrm{~cm}$ height of the plant and 13 pods were recorded at the time of maturity in control condition.

In second experimental set Moongbean cultivated under soil + Compost condition, it gave better yield compared to control i.e. $7.85 \mathrm{~g}$ per plant. Twelve numbers of leaves recorded after 21 days of plantation. At the time of maturity height of plant was recorded $25 \mathrm{~cm}$. and 16 numbers of pods were counted per plant and also recorded total number of grains 133.

Third set was designed with soil + different algal powder i.e. 1) Soil + Cladophora crispata, 2) Soil + Spirogyra jugalis, 3) Soil + Chara fragilis, 4) Soil + Synechococcus aeruginosus, 5) Soil + Spirulina plantensis.

Apart from these five combinations soil + Spirogyra jugalis gave good yield i.e. $8.96 \mathrm{~g}$. per plant. This combination also showed maximum height $30 \mathrm{~cm}$. and 17 pods per plant at the time of maturity. Fourteen leaves were recorded after 21 days of growth and 140 grains recorded after harvesting.

Among these five combinations soil + Spirulina platensis gave less yield i. e. $6.84 \mathrm{~g}$ per plant and other parameters also recorded which were minimum compared to all other algal combinations were studied.

In fourth experimental set algal powder combined with soil and compost. This combination gave best result compared to first three experimental sets. In this experiment plants cultivated with soil + Compost + Synechococcus aeruginosus showed maximum yield compared to other algaes i.e. $12.48 \mathrm{~g}$ per plant.

Plants cultivated under these combinations also showed maximum number of pods per plant and total number of grains i.e. 20 and 178 respectively. It also showed maximum height of the plant i.e. $30 \mathrm{~cm}$ at the time of harvesting and also recorded maximum number of leaves i.e. 17 after 21 days of growth. 


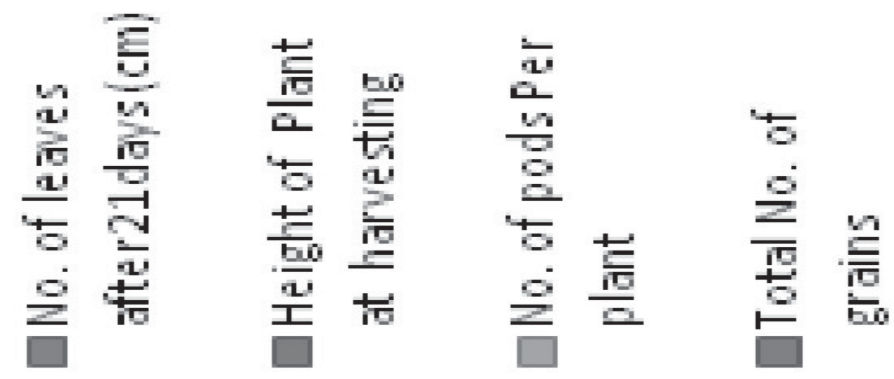

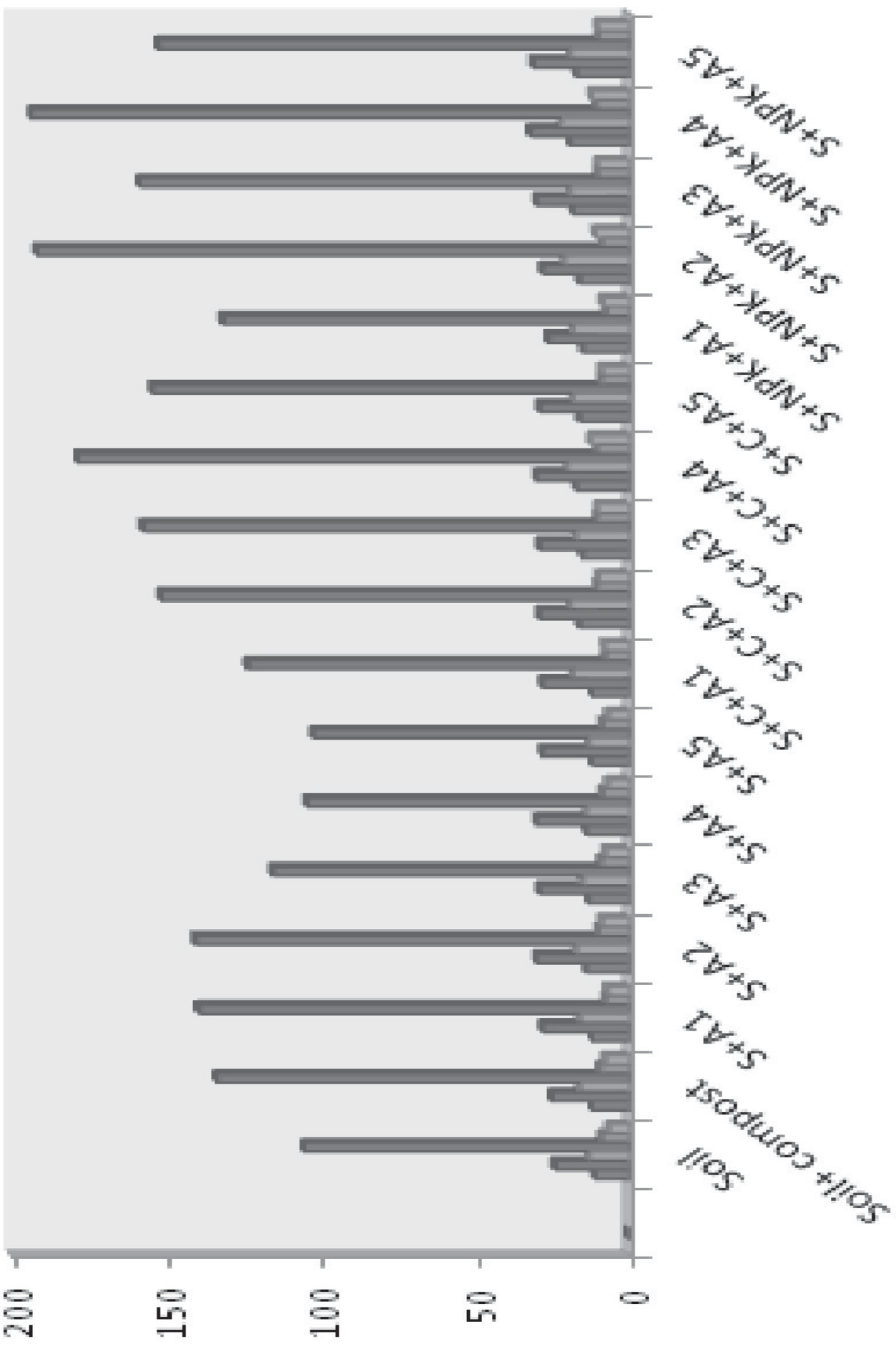



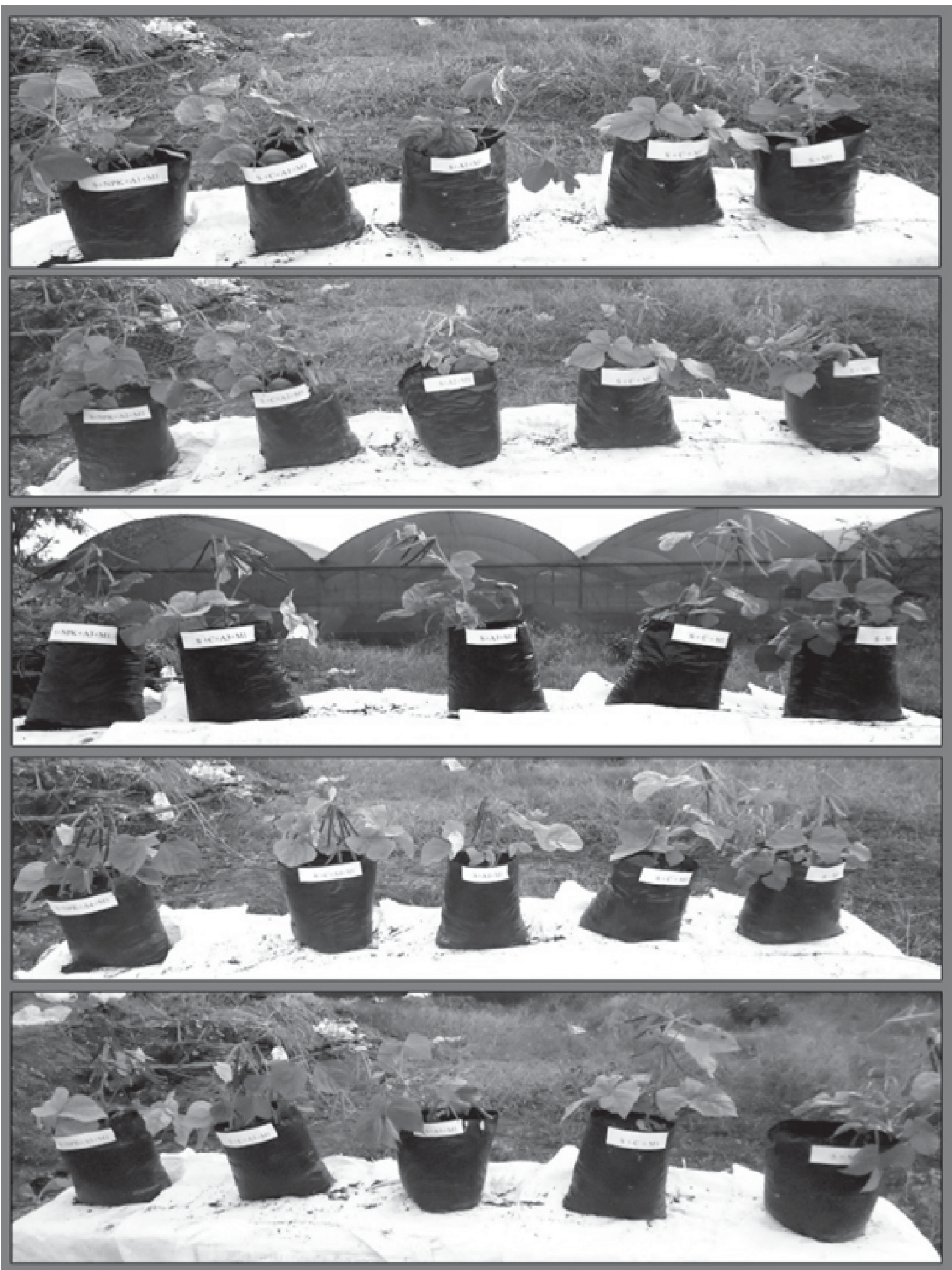

Fig. 2 : Effect of algal powder on growth of Moongbean plant 
In all combinations Soil + Compost + Cladophora crispata gave less yield $8 \mathrm{~g}$ per plant. At the time of maturity height- $28 \mathrm{~cm}$, Number of Pods per plant-18, Total number of grains i.e.123 recorded which was minimum compared to all soil + Compost + different algal combinations.

In the last set it was observed that Soil + NPK (19:19:19) + Synechococcus aeruginosus gave higher yield $12.27 \mathrm{~g}$ and soil + NPK (19:19:19) + Cladophora crispata gives minimum yield $8.62 \mathrm{~g}$.

At the time of maturity soil + NPK (19:19:19) + Synechococcus aeruginosus showed maximum height i.e. $32 \mathrm{~cm}$ and also recorded maximum number of pods i.e. 22 pods per plant compared to all experimental sets (Soil, Soil+ Compost, Soil + Algae and Soil + Compost + algae).

Plants cultivated under different combinations with different experimental sets after maturity average length of the pods also measured and it was found that the plants cultivated under Soil+ NPK+ Synechococcus aeruginosus showed maximum length $10.7 \mathrm{~cm}$ followed by soil+ Compost + Synechococcus aeruginosus $10.5 \mathrm{~cm}$ and then soil+ Spirogyra jugalis $9.9 \mathrm{~cm}$ respectively.

Plants cultivated under controlled condition showed $8.9 \mathrm{~cm}$ length of pod and similarly soil+ Compost combinations showed $9.5 \mathrm{~cm}$ length of pod.
From the above experimental data (Table-1, Graph 1) it was observed that algae act as a biofertilizer and it gives additional supplement of nutrient to the soil that's why it trigger (boost) the growth and yield of selected plants .

Overall it was observed that algal powder combined with soil gave good results and the same selected algal powder when it combined with soil+ compost it gave best results, but when these powders combined with soil+ NPK it gave better results and all the parameters which were recorded also maximum. From the above data it was observed that apart from five algae Synechococcus aeruginosus alga gave higher yield in all three combinations (soil+ algae, soil+ compost+ algae, soil+ $\mathrm{NPK}+$ algae) in Moongbean plants.Moongbean were treated with different selected algal powders,Cladophora crispata and spirulina platensis gives minimum yield

\section{Conclusion}

Blue green algae as well as other algal members are the good source of biofertilizer. For the experimental study, selected algae used as biofertilizer or used as supplement with organic fertilizers as well as inorganic fertilizers and it proves that algae are very good supplements to the inorganic fertilizers as well as organic fertilizers. It helps to increase the yield and productivity of Moongbean crop.

\section{References}

1. Arif M, Gupta R, Joshi MC. Studies on the use of cyanobacteria as biofertilizer for vegetable cultivation in hydroponic system, in Schirmacher oasis region, East Antarctica. Eleventh Indian expedition to Antarctica scientific report. Department of ocean development. Technical publication. 1995; 9: 243-246.

2. El-Barody GS, Moussa MY, Shallan AM, Ali AM, Sabh ZA, Shalaby AE. Contribution to the Aroma, Biological Activities, Minerals, Protein, Pigments and Lipid Contents of the Red Alga, Aspara gopsis taxiformes (Delie) Trevisan. Journal of Applied Sciences Research. 2007; 3(12): 1825-1834.

3. Gupta $A B$, Shukla AC. Studies on the nature of algal growth promoting substances and their influence on growth, yield and protein content of rice plants. Labdev Journal of Science and Technology. 1967; 5: 162-163.

4. Karthikeyan N, Prasanna R, Nain L, Kaushik BD. Evaluating the potential of plant growth promoting cyanobacteria as inoculants for wheat. European Journal of Soil Biology. 2007; 43: 23- 30.

5. Lozano MS, Verde Star J, Maitic PK, Orandy CA, Gaona RH, Aranada HE, Rojas GM. Effect of an algal extract and several plant growth regulators on the nutritive value of Potatoes (Solanum tuberosum L. Var. Gigant), archives hat in oamericanos de Nuticion. 1999; 49: 166-170.

6. Maqubela MP, Mnkeni PNS, Malamissa O, Pardo MT, Acqui LPD. Nostoc cyanobacterial inoculation in South African agricultural soils enhances soil structure, fertility and maize growth. Plant and Soil. 2008; 315: 79-92.

7. Mohan VR, Venkataraman K, Murugewari R, Muthuswami S. Effect of Crude an commercial seaweed extract on seed germination and seeding growth in Cajanus cajan L. Phykos. 1994; 33: 47-51.

8. Rodgers GA, Bergman B, Henriksson E, Udris N. Utilization of blue-green algae as biofertilizers. Plant and Soil. 1979; 52: 99-107. 
9. Saadatnia H, Riahi H. Cyanobacteria from paddy-fields in Iran as a biofertilizer in rice plants. Plant Soil Environment. 2009; 55(5): 207-212.

10. Sabh AZ, Shallan AM. Effect of organic fertilization on Bean (Vicia faba L.) by using different marine macroalgae in relation to the morphological, anatomical characteristics and chemical constituents of the plant. Australian Journal of Basic and Applied Sciences. 2008; 4: 1076-1091.

11. Singh PK. Biofertilization of rice crop. pp. 109-114. In: S.P. Sena. \& P.C. Palit (eds). Biofertilization polentialities and problems. Plant Physiology Forum. 1988.

12. Safinaz AF, Ragaa AH. Effect of some red marine algae as biofertilizers on growth of maize (Zea mayz L.) plants International Food Research Journal. 2013; 20(4): 1629-1632.

13. Shariatmadari Z, Riahi $\mathrm{H}$, Shokravi S. Study of soil blue-green algae and their effect on seed germination and plant growth of vegetable crops Rostaniha. 2011; 12(2): 101-110

14. Thajuddin N, Subramanian G. Cyanobacterial biodiversity and potential application in biotechnology. Current Science. 2005; 89: 47-57.

15. Thirumaran G, Arumugam M, Arumugam R, Anantharaman P. Effect of Seaweed Liquid Fertilizer on Growth and Pigment Concentration of Abelmoschus esculentus (I) medikus American-Eurasian Journal of Agronomy. 2009; 2 (2): 57-66.

16. Venkataraman GS. Algal biofertilizer and rice cultivation. Today and Tomorrows Printer and Publishers. New Delhi. 1972; pp. 71.

17. Venkataraman K, Mohan VR, Murugeswar R, Muthusamy M. Effect of crude commercial seaweed extract on seed germination and seeding growth in green gram and black gram. Seaweed Research and Utilisation. 1993; 16: $23-28$. 